\title{
Fecundity of Atlantic Herring (Clupea harengus) from Three Spawning Areas in the Western Gulf of Maine, 1969 and 1982
}

\author{
Kevin H. Kelly and David K. Stevenson \\ Maine Department of Marine Resources, Fishery Research Laboratory \\ West Boothbay Harbor, Maine 04575, USA
}

\begin{abstract}
Length-specific fecundities of mature Atlantic herring (Clupea harengus L.) were estimated from samples which were collected at three spawning areas along the Maine coast in 1969 and 1982. Fecundities were different between central and eastern Maine and between central and western Maine in 1969 but not between eastern and western Maine. Discrete spawning groups could not be distinguished on the basis of fecundity in 1982. Fecundity was, for all areas combined, significantly higher in 1982 than in 1969 for fish $>29 \mathrm{~cm}$ in length, with increasing divergence of the length-specific fecundity curves for larger fish. Predicted fecundities for 1982 were similar to published 1980 estimates for the same stock, and the 1969 fecundities were similar to published data for 1963-64. The lower fecundities in the 1960's prevailed at a time when the Gulf of Maine herring stock was more than twice as large as it was in the early 1980's.
\end{abstract}

\section{Introduction}

Fecundity is an important biological characteristic which is used, in conjunction with information on egg and larval abundance and age structure, to estimate the biomass and spawning potential of fish populations and to predict changes in population size under varying age-specific mortality regimes. Fecundity estimates have also been used, along with other biological characters, as indicators of stock differentiation. Several fecundity studies of Atlantic herring (hereinafter called "herring") have been carried out on populations in the Northwest Atlantic (Farran, 1938; Hickling, 1940; Kandler and Dutt, 1958; Baxter, 1959; Bridger, 1961; Burd and Howlett, 1974) and in the Northwest Atlantic (Yudanov, 1966; Perkins and Anthony, 1969; Draganik and Rast, 1970; Hodder, 1972; Messieh, 1976). In most cases where fecundity estimates were used for stock discrimination purposes, comparisions were made between stocks whose identities had already been fairly well established on the basis of other characteristics. More recent studies have relied on statistical comparisons of fecundity-length and, in some cases, fecundity-weight relationships for herring from different spawning locations and seasons. Perkins and Anthony (1969) reported fecundity differences among the Georges Bank, Gulf of Maine and Nova Scotia autumn-spawning populations. Hodder (1972) determined that autumn-spawners in Newfoundland waters were more fecund than spring-spawners. The same conclusion was reached by Messieh (1976) who compared fecundities of spring-spawning and autumnspawning populations in the Gulf of St. Lawrence and Nova Scotia waters. Analyses of fecundity-length data by the latter two authors among spring-spawning pop- ulations in Newfoundland waters and among autumnspawning populations in Nova Scotia waters failed to reveal any significant differences. In Europe, differences have been reported between autumn-spawning and spring-spawning populations (Parrish and Saville, 1965) and also among autumn-spawning populations in the North Sea (Baxter, 1959; Burd and Howlett, 1974). Variations in fecundity among spawning populations of herring have been attributed to both genetic and environmental factors (Blaxter and Holliday, 1963; Parrish and Saville, 1965; Hodder, 1972). Herring fecundity has also been reported to vary inversely with egg size and egg weight (Parrish and Saville, 1965; Messieh, 1976; Blaxter and Hunter, 1983). Changes in fecundity have been associated with variations in population density for several marine and freshwater species (LeCren, 1958; Bagenal, 1966; Raitt, 1968; Kipling and Frost, 1969; Mathur et al., 1979).

Herring spawning has been inferred at several locations in coastal and near-coastal waters of the western Gulf of Maine from the capture of fully ripe females (Boyar et al., 1973), from egg-bed and larval surveys (Boyar et al., MS 1973; Cooper et al., MS 1975; Iles and Sinclair, 1982; Graham, 1982; Townsend et al., 1986), and from the presence of eggs on lobster traps (Stevenson, MS 1984). These studies indicated that herring spawn in eastern Maine coastal waters from the Canada-Unted States boundary to about Jonesport $\left(44^{\circ} 32^{\prime} \mathrm{N}\right)$, in Canadian waters south of Grand Manan Island, on various shoals and ledges off central Maine, on Jeffreys Ledge, and in coastal waters of western Maine, New Hampshire and Massachusetts. The major distinguishing feature of herring populations which spawn at the extreme ends of the U.S. Gulf of Maine 
coast is the difference in spawning time. Spawning begins in eastern Maine waters during middle to late August and apparently continues into October (Stevenson, MS 1984; Graham and Sherman, MS 1984). Spawning begins on Jeffreys Ledge in middle to late September (Cooper et al., MS 1975; McCarthy et al., MS 1979) and, judging from the presence of fully mature fish in October, continues into November. No information is available on spawning time and the precise location of spawning sites in central Maine waters.

Herring which spawn on Jeffreys Ledge and along the U.S. coast of the Gulf of Maine have been recognized as a single stock. It has been distinguished from the Georges Bank and southwest Nova Scotia stocks on the basis of differences in phenotypic characters such as growth rates and numbers of fin rays and vertebrae, as well as differences in sizes of spawning populations, larval drift patterns, seasonal adult migrations, and parasite occurrences (see Sindermann, MS 1979 , for summary). A recent study of genetic variability among autumn-spawning and spring-spawning populations in the Northwest Atlantic failed to show any temporally stable differences among autumnspawning stocks in the Gulf of Maine (Kornfield et al., 1982).

The purposes of this study were (i) to compare the fecundities of autumn-spawning herring from three areas in the western Gulf of Maine (Fig. 1); and (ii) to determine whether there has been a change in fecundity of herring in these areas since the 1960's, when the stock was much larger than in recent years.

\section{Materials and Methods}

Samples of mature female herring were obtained from commercial catches at various locations along the western Gulf of Maine in August-September 1982 (Table 1, Fig. 1). For convenience, the three areas were defined as western, central and eastern Maine although the western area extends southward along the New Hampshire and Massachusetts coasts and the eastern area extends northward to southern Canadian waters. Fecundity was estimated only for fish with well developed ovaries (maturity stages IV and V, according to Boyar, 1968). Specimens with completely ripe ovaries (stage VI) were not included because capture and handling may have induced the loss of some eggs. The herring were measured as total length to the nearest $0.1 \mathrm{~cm}$. Ovaries were removed and preserved in a 10\% formalin solution (with seawater) which hardened the eggs and made them easily separable for counting purposes.

Fecundities of 237 females from the 1982 collections were estimated by the gravimetric technique, as

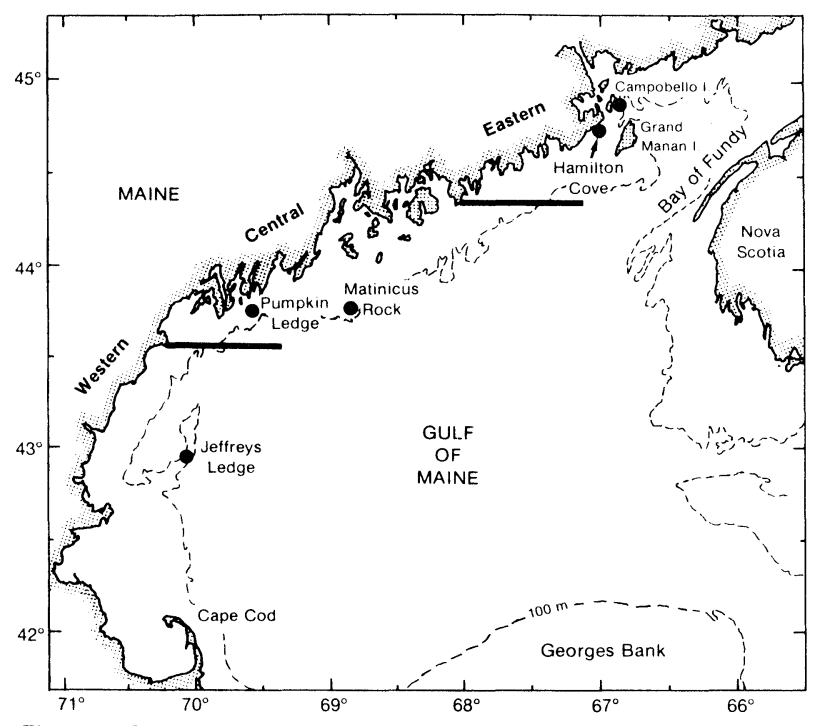

Fig. 1. Gulf of Maine region with sampling locations and place names noted in the text.

TABLE 1. Numbers of herring for fecundity estimation from various locations in the Gulf of Maine, 1969 and 1982. (Number of samples in parentheses.)

\begin{tabular}{clllr}
\hline \hline Year & \multicolumn{1}{c}{ Area } & \multicolumn{1}{c}{ Catch location } & \multicolumn{1}{c}{ Dates } & No. \\
\hline 1969 & Eastern Maine & Campobello I. (N.B.) & Aug 18 & $68(1)$ \\
& Central Maine & Matinicus Rock & Aug 19 & $101(1)$ \\
& Western Maine & Jeffreys Ledge & Jul 31 & $46(1)$ \\
1982 & Eastern Maine & Hamilton Cove & Aug 18 & $34(1)$ \\
& & & Sep 08-28 & $46(2)$ \\
& Central Maine & Matinicus Rock & Aug 07-16 & $36(3)$ \\
& & Pumpkin Ledge & Aug 08-19 & $41(3)$ \\
& Western Maine & Jeffreys Ledge & Sep 09-28 & $80(5)$ \\
\hline
\end{tabular}

described by Wolfert (1969). Both ovaries from each fish were blotted dry and weighed to the nearest $0.1 \mathrm{~g}$. Three samples of about 200-400 eggs each were removed from one of the ovaries, weighed to the nearest $0.001 \mathrm{~g}$, and fixed in a petri-dish with agar. Eggs were counted under a binocular microscope. Fecundity $(F)$ of each fish was estimated by the equation

$$
\mathrm{F}=\mathrm{W} \times\left(\Sigma \mathrm{E}_{\mathrm{i}} / \Sigma \mathrm{w}_{\mathrm{i}}\right)
$$

where $W$ is weight $(g)$ of both ovaries, and $E_{i}$ is egg count and $w_{i}$ is weight $(g)$ of each sample $(i=3)$.

In addition to the 1982 data, unpublished fecundity estimates for 216 herring from the same general localities in 1969 (Table 1) were kindly provided by F. E. Perkins, formerly with the U.S. Bureau of Commercial Fisheries, West Boothbay Harbor, Maine, and now with the Maine Department of Environmental Protection. These length-specific fecundity estimates were based on total egg counts with an automatic egg-counting device (Boyar and Clifford, 1967). 
Fecundity-length relationships were derived for data for each of the three areas in 1969 and 1982 by log (base 10) transformation of the power function $\mathrm{F}=\mathrm{aL}^{\mathrm{b}}$ to the linear regression equation

$$
\log F=\log a+b \log L
$$

where $F$ is fecundity (number of eggs) and $L$ is total length of fish in centimeters. Lines were fitted by the least-squares method to log-transformed data and analysis of covariance was used to test for differences between slopes and intercepts among areas and between years.

Finally, all data for each year were combined and the parameters and associated statistics of the fecundity-length relationship were calculated by fitting a straight line to the log-transformed data by standard least-squares methods and also by directly fitting a power curve to the actual data by iterative non-linear procedures. For each model and year, mean fecundities were predicted for $1-\mathrm{cm}$ length intervals.

\section{Results}

The log-transformed linear relationships produced highly significant correlations between log fecundity and log length $(P<0.01)$, with $57 \%$ or more of the variation in log fecundity being attributed to its linear regression on log length in all cases except the 1969 sample from western Maine for which only about $19 \%$ of the variance of $\log$ fecundity is associated with log length (Table 2 ). The variability associated with the data from each area was greater in 1969 than in 1982. Most of the variability in the 1969 data was associated with the single sample from Jeffreys Ledge (Table 1).

Analyses of covariance failed to reveal any differences in slopes or intercepts of the linear regressions among areas in 1982 (Table 3). Although the slopes of the 1969 regressions did not differ significantly, the intercepts were different, indicating that the fecundities for the three areas were not homogoneous. Between-area analyses showed that fecundities for the two most distant areas (eastern and western Maine) were essentially the same (Table 3). Between year differences were observed within all three areas in terms of either slope or intercept (Table 4), indicating that fecundities in 1969 and 1982 were not the same.

The combined data for all areas were used to calculate log-transformed linear regressions and nonlinear power functions for 1969 and 1982 separately. For both years, the two models are expressed as power curves in the form $\mathrm{F}=\mathrm{aL}^{\mathrm{b}}$ (Fig. 2). The log-linear model accounted for $87 \%$ of the variation in the combined 1982 fecundity data and for $52 \%$ of the variation in the combined 1969 fecundity data. In 1969, fecundity estimates ranged from 52,000 to 194,000 eggs for herring
TABLE 2. Linear regression and correlation parameters of log fecundity-log length relationships by year and area for Gulf of Maine herring samples.

\begin{tabular}{ccrccc}
\hline \hline Year & Area & No. & Log a & $b$ & $r^{2}$ \\
\hline \multirow{1}{*}{1969} & Eastern Maine & 68 & -0.9689 & 4.000 & 0.57 \\
& Central Maine & 101 & -1.7229 & 4.530 & 0.66 \\
& Western Maine & 46 & 0.0665 & 3.313 & 0.19 \\
1982 & & 80 & -3.8472 & 5.983 & 0.84 \\
& Eastern Maine & 77 & -2.4827 & 5.081 & 0.79 \\
& Central Maine & 80 & -3.9160 & 6.032 & 0.87 \\
& Western Maine & & & & \\
\hline
\end{tabular}

TABLE 3. Analysis of covariance results for log fecundity-log length relationships for Gulf of Maine herring samples between areas in 1969 and 1982. (** indicates significance at $P=$ 0.01 level.)

\begin{tabular}{|c|c|c|c|c|}
\hline Year & Comparison & Variation source & df & $\mathrm{F}$ \\
\hline \multirow[t]{8}{*}{1969} & All areas & Between intercepts & 2,211 & $10.10^{\star \star}$ \\
\hline & & Between slopes & 2,209 & 1.30 \\
\hline & Eastern and & Between intercepts & 1,166 & $15.91^{* *}$ \\
\hline & Central Maine & Between slopes & 1,165 & 0.97 \\
\hline & Eastern and & Between intercepts & 1,111 & 0.01 \\
\hline & Western Maine & Between slopes & 1,110 & 0.74 \\
\hline & Central and & Between intercepts & 1,144 & $12.89^{\star *}$ \\
\hline & Western Maine & Between slopes & 1,143 & 2.20 \\
\hline \multirow[t]{2}{*}{1982} & All areas & Between intercepts & 2,233 & 1.28 \\
\hline & & Between slopes & 2,231 & 2.74 \\
\hline
\end{tabular}

TABLE 4. Analysis of covariance results for log fecundity-log length relationships for Gulf of Maine herring samples between years in eastern, central and western Maine. $\left(^{\star *}\right.$ indicates significance at $P=0.01$ and ${ }^{*}$ at $P=0.05$ )

\begin{tabular}{clcc}
\hline \hline \multicolumn{1}{c}{ Area } & Variation source & df & $\mathrm{F}$ \\
\hline Eastern Maine & Between intercepts & 1,145 & $21.80^{\star *}$ \\
& Between slopes & 1,144 & $10.61^{*}$ \\
Central Maine & Between intercepts & 1,176 & $40.88^{\star *}$ \\
& Between slopes & 1,175 & 1.52 \\
Western Maine & Between intercepts & 1,123 & $59.22^{* *}$ \\
& Between slopes & 1,122 & $7.94^{*}$ \\
\hline
\end{tabular}

with a length range of $27.6-35.8 \mathrm{~cm}$. In 1982 , more fish less than $30 \mathrm{~cm}$ were sampled, and the fecundity estimates varied from 17,300 to 301,000 eggs for herring with a length range of $24.3-38.0 \mathrm{~cm}$. The single $38 \mathrm{~cm}$ specimen was not included in the 1982 regression analysis. Observed mean fecundities varied from 68,320 to 154,560 eggs for $28-34 \mathrm{~cm}$ herring in 1969 and from 35,360 to 190,950 eggs for $24-35 \mathrm{~cm}$ herring in 1982 (Table 5).

Both fecundity-length models predicted that mean fecundities of fish greater than $29 \mathrm{~cm}$ in length were greater in 1982 than in 1969 (Fig. 3, Table 6). Also, for both models, the magnitude of the between-year differences in predicted fecundities increased with increasing length. The values of the exponent (b) were 


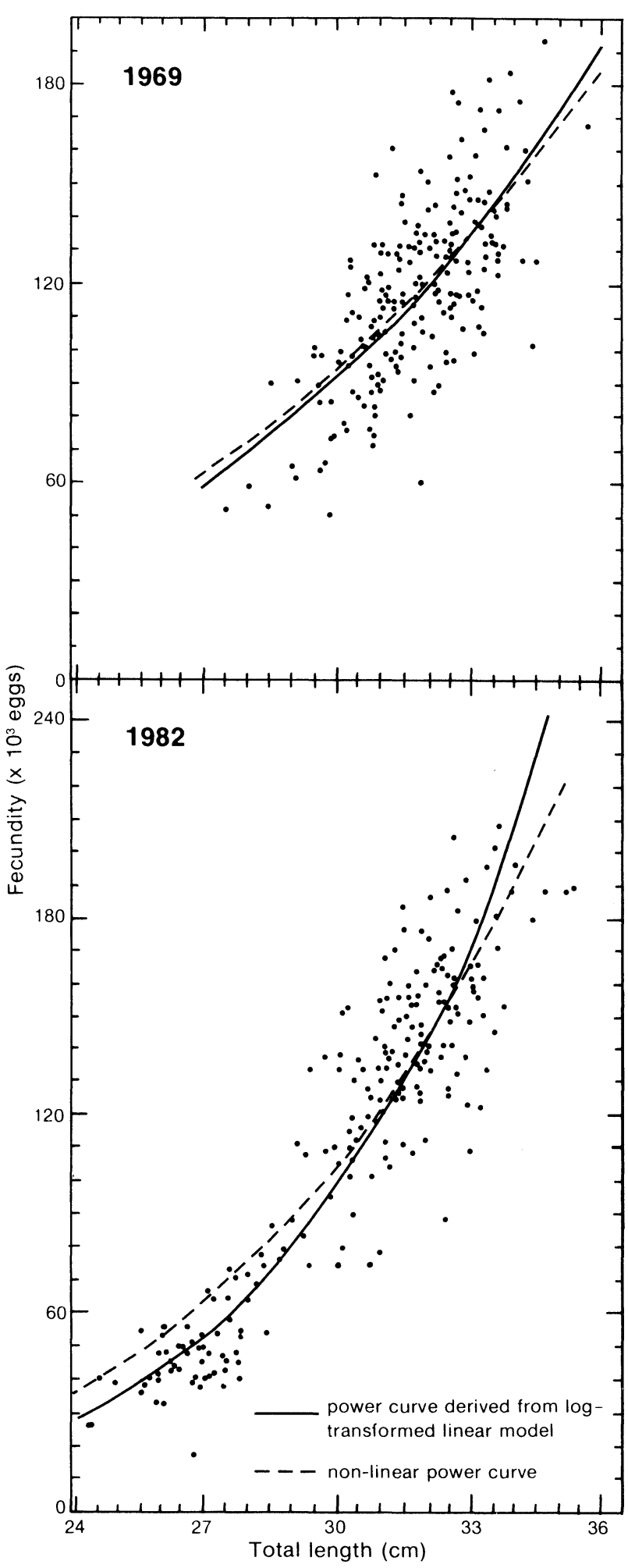

Fig. 2. Length-specific fecundities of herring from western Gulf of Maine spawning areas (combined) in 1969 and 1982, and curves representing the fecundity-length relationships (see Fig. 3 for equations)

4.81 and 5.89 (standard errors 0.164 and 0.151 ) in 1982 and 3.77 and 4.16 (standard errors 0.268 and 0.271 ) in 1969 for the non-linear and log-linear models respec-

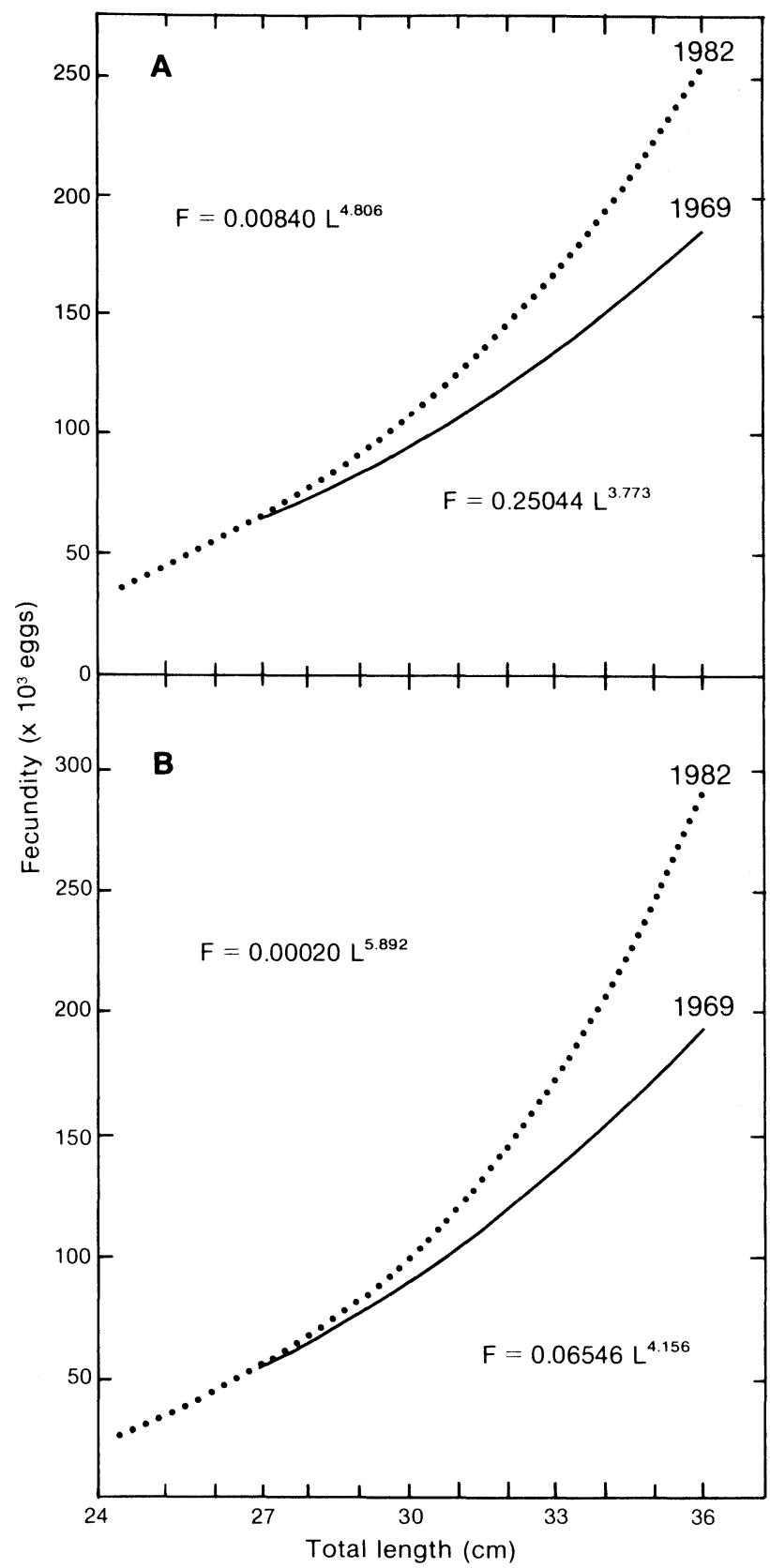

Fig. 3. Comparison of fecundity-length relationships for 1969 and 1982 from (A) power curve fit to untransformed data, and (B) power curve derived from fit of linear model to logtransformed data.

tively. The rate of change in fecundity as a function of length was significantly different $(P<0.05)$ between years for each model.

For the 1982 data, mean fecundities of $24-36 \mathrm{~cm}$ herring were predicted by the non-linear model to range from 36,100 to 253,400 eggs and by the log-linear model to range from 26,700 to 290,800 eggs (Table 6 ) The 1982 curves intersected at about $31.5 \mathrm{~cm}$ (fish length), with the log-linear model giving the higher estimates for the larger fish and the non-linear model 
giving higher estimates for the smaller fish (Fig. 2). For the 1969 data, mean fecundities of $27-36 \mathrm{~cm}$ fish were predicted by the non-linear model to range from 63,000 to 186,500 eggs, with a similar range in predicted values by the log-linear model.

For both models, the percentage increase in predicted fecundities from 1969 to 1982 became progressively greater for larger fish (Table 6), the increase for $27-36 \mathrm{~cm}$ fish being from 1 to $36 \%$ for the non-linear model and from -8 to $51 \%$ for the log-linear model. The apparent reduced fecundities of fish at 27 and $28 \mathrm{~cm}$ in 1982 (log-linear model) were not significantly different from the 1969 fecundities for fish of the same lengths. For the log-linear model, interval estimates of fecundity-at-length in 1969 and 1982 were significantly different for fish from 30 to $36 \mathrm{~cm}$ in length (Table 6).

\section{Discussion}

The results of this study support the view that herring from coastal and near-coastal waters of the

TABLE 5. Numbers of herring and observed mean fecundities by length in 1969 and 1982 samples from the western Gulf of Maine.

\begin{tabular}{crcrrr}
\hline \hline \multirow{2}{*}{$\begin{array}{c}\text { Length } \\
(\mathrm{cm})\end{array}$} & No. & Fecundity & & No. & \multicolumn{2}{c}{ Fecundity } \\
\cline { 2 - 3 } & - & - & 3 & 35,362 \\
\hline 24 & - & - & 8 & 41,849 \\
25 & - & - & 24 & 45,648 \\
26 & - & - & 23 & 52,116 \\
27 & 3 & 68,321 & 10 & 74,064 \\
28 & 14 & 80,129 & 10 & 105,655 \\
29 & 33 & 99,332 & 33 & 118,307 \\
30 & 60 & 116,687 & 59 & 142,613 \\
31 & 54 & 126,885 & 43 & 154,938 \\
32 & 41 & 139,019 & 18 & 167,649 \\
33 & 9 & 154,556 & 3 & 189,792 \\
34 & - & - & 2 & 190,948 \\
35 & & & & \\
\hline
\end{tabular}

western Gulf of Maine between Jeffreys Ledge and eastern Maine should be treated as a single spawning population. If some degree of reproductive isolation existed between groups of herring which spawned at different locations and times along the coast in 1982, it was not evident from the fecundity-length relationships in this study. Although covariance analysis of the 1969 data revealed significant differences in the intercepts of the log-transformed fecundity-length relationships for eastern and central Maine and also for central and western Maine (Table 3), the homogeneity between the two most distant spawning areas (eastern and western Maine) does not support the discrete spawning group hypothesis.

The importance of the eastern Maine spawning grounds was emphasized in early reports (Moore, 1898; Bigelow and Schroeder, 1953), but attention in recent years has shifted to the Jeffreys Ledge area and Southwest Nova Scotia as the primary spawning grounds in the Gulf of Maine. In discussions about the structure of herring stocks in the Gulf of Maine, the status of herring which spawn in eastern Maine has been unclear. Neither Ridgway (MS 1975) nor Sindermann (MS 1979) mentioned eastern Maine specifically when distinguishing between the Nova Scotian and Gulf of Maine stocks, although Boyar et al., (1973) included eastern Maine in their summary of herring spawning sites in the Gulf of Maine. The affinity of herring which spawn along the eastern Maine coast with those which spawn at Grand Manan and in New Brunswick waters along the western side of the Bay of Fundy remains unclear.

In addition to the fecundity estimates for the Gulf of Maine herring stock from this study of data collected in 1969 and 1982, Perkins and Anthony (1969) provided estimates from an ordinary linear regression of fecundity on length data (collected in 1963 and 1964) for the Gulf of Maine as a whole, and Morse and Morris (MS

TABLE 6. Predicted mean fecundities of Gulf of Maine herring by length from the nonlinear and log-linear models and percentage changes from 1969 to 1982.

\begin{tabular}{|c|c|c|c|c|c|c|}
\hline \multirow{3}{*}{$\begin{array}{c}\text { Length } \\
(\mathrm{cm})\end{array}$} & \multicolumn{4}{|c|}{ Predicted mean fecundity } & \multicolumn{2}{|c|}{$\%$ change $1969-82$} \\
\hline & \multicolumn{2}{|c|}{1969} & \multicolumn{2}{|c|}{1982} & \multirow{2}{*}{$\begin{array}{l}\text { Non- } \\
\text { linear }\end{array}$} & \multirow{2}{*}{$\begin{array}{l}\text { Log } \\
\text { linea }\end{array}$} \\
\hline & Non-linear & Log-linear & Non-linear & Log-linear & & \\
\hline 24 & & & 36,106 & 26,670 & & \\
\hline 25 & & & 43,932 & 33,922 & & \\
\hline 26 & & & 53,045 & 42,741 & & \\
\hline 27 & 62,985 & $58,234^{a}$ & 63,594 & $53,385^{a}$ & 1.0 & -8.3 \\
\hline 28 & 72,249 & $67,736^{\mathrm{a}}$ & 75,739 & $66,142^{\mathrm{a}}$ & 4.8 & -2.4 \\
\hline 29 & 82,477 & $78,371^{\mathrm{a}}$ & 89,653 & $81,333^{a}$ & 8.7 & 3.8 \\
\hline 30 & 93,731 & 90,229 & 105,517 & 99,316 & 12.6 & 10.1 \\
\hline 31 & 109,075 & 103,402 & 123,527 & 120,482 & 16.5 & 16.5 \\
\hline 32 & 119,573 & 117,987 & 143,890 & 145,266 & 20.3 & 23.1 \\
\hline 33 & 134,294 & 134,083 & 166,824 & 174,142 & 24.2 & 29.9 \\
\hline 34 & 150,305 & 151,795 & 192,560 & 207,632 & 28.1 & 36.8 \\
\hline 35 & 167,677 & 171,229 & 221,345 & 246,303 & 32.0 & 43.8 \\
\hline 36 & 186,480 & 192,497 & 253,436 & 290,773 & 35.9 & 51.1 \\
\hline
\end{tabular}

a Overlap in $95 \%$ interval estimates of fecundity between years within length groups. 
TABLE 7. Predicted mean fecundities of Gulf of Maine herring from various sources in the 1960's and early 1980's.

\begin{tabular}{|c|c|c|c|c|}
\hline \multirow{2}{*}{$\begin{array}{l}\text { Length } \\
(\mathrm{cm})\end{array}$} & \multicolumn{4}{|c|}{ Fecundity (000 eggs) } \\
\hline & $1963-64^{\mathrm{a}}$ & $1969^{c}$ & $1980^{6}$ & $1982^{c}$ \\
\hline 24 & - & - & - & 36 \\
\hline 25 & 18 & - & 44 & 44 \\
\hline 26 & 33 & - & 52 & 53 \\
\hline 27 & 49 & 63 & 63 & 64 \\
\hline 28 & 64 & 72 & 75 & 76 \\
\hline 29 & 79 & 82 & 88 & 90 \\
\hline 30 & 95 & 94 & 104 & 106 \\
\hline 31 & 110 & 106 & 121 & 124 \\
\hline 32 & 126 & 120 & 141 & 144 \\
\hline 33 & 141 & 134 & 163 & 167 \\
\hline 34 & - & 150 & 188 & 193 \\
\hline 35 & - & 168 & 216 & 221 \\
\hline 36 & - & 186 & 246 & 253 \\
\hline No. of fish & 205 & 216 & 131 & 237 \\
\hline
\end{tabular}

a Perkins and Anthony (1969).

b Morse and Morris (MS 1981).

c. This study.

1981) analyzed data (collected in 1980) that were primarily from the southwestern Gulf of Maine. Predicted fecundities of herring by $1 \mathrm{~cm}$ length-groups in 1980 and 1982 were very similar over all lengths (Table 7). The 1963-64 and 1969 fecundities were also similar over a more limited length range and were lower than those of the early 1980's.

According to Fogarty and Clark (MS 1983), the stock size of adult herring (age 4+) in the Gulf of Maine has generally declined since 1968 , with partial recoveries due to recruitment of strong year-classes to the adult population in 1974, 1980 and 1981 . The lower 1969 fecundities prevailed at a time when the estimated stock size was more than twice as large as that which was estimated in 1982. The coincidence of such an increase in fecundity with diminished stock size indicates that fecundity of herring may be densitydependent. Increased fecundity may represent a way by which herring respond to reduced population size. Density-dependence has also been invoked to explain observed changes in fecundity of herring on Georges Bank between 1963-64 and 1968 (Anthony and Waring, MS 1980) and before and after 1973 in the Gulf of St. Lawrence, the Scotian Shelf and Georges Bank (Messieh et al., MS 1985). This absence of temporal stability underscores the importance of obtaining current fecundity estimates for stock discrimination and assessment purposes.

\section{Acknowledgements}

We are grateful to many people at the Fishery Research Laboratory of the Maine Department of Marine Resources for their assistance. In particular, we thank Lew Lozier for making field collections, Ted Creaser and David Libby for valuable discussions of herring management and biology, Jean Chenoweth for advice on laboratory techniques, Margaret Hunter and David Sampson for assistance with data analysis, Vicki Averill for typing the manuscript, and Joseph Graham for reviewing an earlier draft of the paper. Frank Perkins of the Maine Department of Environmental Protection generously made his 1969 fecundity available to use, Wallace Morse of the U.S. National Marine Fisheries Service provided information on estimating fish fecundity, and Jim Rollins and Kim Knowlton of the Bigelow Laboratory for Ocean Sciences drafted the illustrations. Irving Kornfield of the University of Maine and Vaughn Anthony of the U.S. National Marine Fisheries Service provided valuable comments on an earlier draft of the manuscript. Computer facilities were provided by the University of Maine at Orono.

\section{References}

ANTHONY, V. A., and G. WARING. MS 1980. Estimates of herring spawning stock biomass and egg production for the Georges Bank-Gulf of Maine region. NAFO SCR Doc., No. 135, Serial No. N209, 38 p.

BAGENAL, T. B. 1966. The ecological and geographical aspects of the fecundity of plaice. J. Mar. Biol. Assoc. U.K., 46: 161-186.

BAXTER, I. G. 1959. Fecundities of winter-spring and summer-autumn herring spawners. ICES J. Cons., 25 73-80.

BIGELOW, H. B., and W. C. SCHROEDER. 1953. Fishes of the Gulf of Maine. Fish. Bull. U.S., 53: 577 p.

BLAXTER, J. H. S., and F. G. T. HOLLIDAY. 1963. The behaviour and physiology of herring and other clupeids. Adv. Mar. Biol., 1: 261-393.

BLAXTER, J. H. S., and J. R. HUNTER. 1983. The biology of the clupeoid fishes. Adv. Mar. Biol., 20: 1-223.

BOYAR, H. C. 1968. Age, length and gonadal stages of herring from Georges Bank and the Gulf of Maine. ICNAF Res. Bull., 5: 49-61.

BOYAR, H. C., and R. A. CLIFFORD. 1967. An automatic device for counting dry fish eggs. Trans. Amer. Fish. Soc., 96: 361-363.

BOYAR, H. C., R. A. COOPER, and R. A. CLIFFORD. MS 1973. A study of the spawning and early life history of herring (Clupea harengus harengus L.) on Jeffreys Ledge in 1972. ICNAF Res. Doc., No. 96, Serial No. 3054, 27 p.

BOYAR, H. C., R. R. MARAK, F. E. PERKINS, and R. A. CLIFFORD. 1973. Seasonal distribution and growth of larval herring (Clupea harengus L.) in the Georges Bank-Gulf of Maine area from 1962 to 1970. ICES J. Cons., 35: 36-51.

BRIDGER, J. P. 1961. On fecundity and larval abundance of Downs herring. Fish. Invest. Lond., Ser. II, 23(3): $30 \mathrm{p}$.

BURD, A. C., and G. J. HOWLETT. 1974. Fecundity studies on North Sea herring. ICES J. Cons., 35: 107-120.

COOPER, R. A., J. R. UZMANN, R. A. CLIFFORD, and K. J. PECCI. MS 1975. Direct observations of herring (Clupea harengus harengus L.) egg beds on Jeffreys Ledge, Gulf of Maine, in 1974. ICNAF Res. Doc., No. 93, Serial No. 3573, $6 \mathrm{p}$.

DRAGANIK, B., and B. RAST. 1970. The fecundity of Georges Bank herring. ICNAF Redbook, 1970(III): 117-122.

FARRAN, G. P. 1983. On the size and number of ova of Irish 
herrings. ICES J. Cons., 13: 91-100.

FOGARTY, J. J., and S. H. CLARK. MS 1983. Status of Atlantic herring resources in the Gulf of Maine region, 1983. U.S. Nat. Mar. Fish. Serv., Northeast Fisheries Center, Woods Hole, Lab. Ref. Doc., No. 83-46, 33 p.

GRAHAM, J. J. 1982. Production of larval herring, Clupea harengus, along the Maine coast, 1964-78. J. Northw. Atl. Fish. Sci., 3: 63-85.

GRAHAM, J. J., and K. SHERMAN. MS 1984. Estimates of spawning period and spawning intensity of Maine herring. Maine Dept. Mar. Resour. Res. Ref. Doc., No. $84 / 15,4$ p. + figs.

HICKLING, C. F. 1940. The fecundity of the herring of the southern North Sea. J. Mar. Biol. Assoc. U.K., 24 : 619-632.

HODDER, V. M. 1972. The fecundity of herring in some parts of the Newfoundland area. ICNAF Res. Bull., 9: 99-107.

ILES, T. D., and M. SINCLAIR. 1982. Atlantic herring: stock discreteness and abundance. Science, 215: 627-633.

KANDLER, R., and S. DUTT. 1958. Fecundity of Baltic herring. ICES Rapp. Proc.-Verb., 143: 99-108.

KIPLING, C., and W. E. FROST. 1969. Variations in the fecundity of pike Esox lucius L. in Windemere. J. Fish. Biol., 1: 221-237.

KORNFIELD, I., B. D. SIDELL, and P. S. GAGNON. 1982. Stock definition in Atlantic herring (Clupea harengus harengus): genetic evidence for discrete fall and spring spawning populations. Can. J. Fish. Aquat. Sci., 39: 1610-1621.

LeCREN, E. D. 1958. Observations on the growth of perch (Perca fluviatilis) over twenty-two years with reference to the effects of temperature and changes in population density. J. Anim. Ecol., 27: 287-334.

MATHUR, D., P. L. MCCREIGHT, and G. NARDACCI. 1979. Variations in fecundity of white crappie in Conowingo Pond, Pennsylvania. Trans. Amer. Fish. Soc., 108: 548-554.

MCCARTHY, K., C. CROSS, R. COOPER, R. LANGTON, K. PECCI, and J. UZMANN. MS 1979. Biology and geology of Jeffreys Ledge and adjacent basins: an unpolluted inshore fishing area, Gulf of Maine, NW Atlantic. ICES C.M. Doc., No. E:44, 12 p.

MESSIEH, S. N. 1976. Fecundity studies on Atlantic herring from the southern Gulf of St. Lawrence and along the Nova Scotia coast. Trans. Amer. Fish. Soc., 105:384-394.
MESSIEH, S., V. ANTHONY, and M. SINCLAIR. MS 1985. Fecundities of Atlantic herring (Clupea harengus L.) populations in the Northwest Atlantic. ICES C.M. Doc., No. $\mathrm{H}: 8,22 \mathrm{p}$.

MOORE, $H$. F. 1898. Observations on the herring fisheries of the northeast coast, with special reference to the vicinity of Passamaquoddy Bay. In Report of the Commissioner for the year ending June 30, 1896, Part XXII. Gov't Printing Office, Washington, D. C., p. 387-442.

MORSE, W. W., and A. MORRIS. MS 1981. Length, weight, age and fecundity of the Atlantic herring, Clupea harengus harengus L., in the western Gulf of Maine, 1980. U.S. Nat. Mar. Fish. Serv., Northeast Fisheries Center, Sandy Hook Lab. Ref. Doc., No. 81-21, 6 p.

PARRISH, B. B., and A. SAVILLE. 1965. The biology of the Northeast Atlantic herring populations. Oceanogr. Mar. Biol. Ann. Rev., 3: 323-373.

PERKINS, F. E., and V. C. ANTHONY. 1969. A note on the fecundity of herring (Clupea harengus harengus L.) from Georges Bank, the Gulf of Maine and Nova Scotia. ICNAF Redbook, 1969(III): 33-38.

RAITT, D. F. S. 1968. The population dynamics of the Norway pout in the North Sea. Mar. Res. Scot., 5: 1-24.

RIDGWAY, G. J. MS 1975. A conceptual model of stocks of herring (Clupea harengus) in the Gulf of Maine. ICNAF Res. Doc., No. 100, Serial No. 3586, 17 p.

SINDERMANN, C. J. MS 1979. Status of Northwest Atlantic herring stocks of concern to the United States. U.S. Nat. Mar. Fish. Serv., Tech. Rep., 23: 449 p.

STEVENSON, D. K. MS 1984. Spawning locations and times for Atlantic herring (Clupea harengus harengus L.) in coastal waters of eastern Maine. Maine Dept. Mar. Resour. Lab. Ref. Doc., No. 84/1, 26 p. + figs.

TOWNSEND, D. W., J. J. GRAHAM, and D. K. STEVENSON. 1986. Dynamics of larval herring (Clupea harengus L.) production in tidally mixed waters of the eastern coastal Gulf of Maine. In Tidal mixing and plankton dynamics, M. Bowman (ed.), Springer-Verlag, New York, N. Y. (in press).

WOLFERT, D. R. 1969. Maturity and fecundity of walleyes from the eastern and western basins of Lake Erie. J. Fish. Res. Board Can., 26: 1877-1888.

YUDANOV, I. G. 1966. Fecundity and efficiency of spawning of Atlantic herring in the Gulf of Maine. Tr. PINRO, Murmansk, 17: 249-262. 
